\title{
Study of the strain gage signals for the control of a micro torque meter
}

\author{
Mucsi C. S.; Aranha, L. C.; Alencar M. C.; Rossi, J. L. \\ Instituto de Pesquisas Energéticas e Nucleares - IPEN - CNEN/SP \\ Av. Prof. Lineu Prestes, 2242 - Cidade Universitária - CEP 05508-00 - São Paulo - SP - Brazil \\ csmucsi@gmail.com
}

\begin{abstract}
The controls of the stresses on the bone-implant and implant-abutment interfaces are crucial for the performance of an implant. Dental implants are a class in itself due to its size, chemical and biological environment. This paper presents a study on the electric signals from a strain gage used in a custommade laboratory micro torque meter specially developed to evaluate the influence of the bone-implant and implant-abutment screwed interfaces on the micro torque signals. The original electric signals were acquired via National Instruments (NI) hardware and real time processed with the Labview ${ }^{\circledR}$ software for the evaluation of noise and its relation to the physical values of interest and equipment precision. The results indicate the need of careful attention to the noise pickup, noise source controls and mechanical amplification of the original signal in order to obtain higher accuracy of the equipment and automated control on the equipment.
\end{abstract}

Keywords: strain gage, prosthesis, abutments, signal analysis, control.

\begin{abstract}
Resumo
O controle dos esforços nas interfaces osso-implante e implante-pilar protético é crucial para o desempenho do implante. Implantes odontológicos formam uma classe própria devido às suas dimensões e ao ambiente bioquímico onde são instalados. Este trabalho apresenta um estudo sobre os sinais elétricos vindos de um extensômetro do tipo strain gage utilizados num micro torquímetro de laboratório, especialmente desenvolvido para avaliar os sinais provenientes de esforços de micro torques nas interfaces osso-implante e implante-pilar protético. Os sinais elétricos originais foram adquiridos via hardware da National Instruments $(\mathrm{NI})$ e numericamente processados pelo ambiente de programação LabView $^{\circledR}$ para a avaliação do ruído e as suas relações com as grandezas físicas de interesse e a precisão do equipamento. Os resultados indicam a necessidade de atenção às fontes e formas de interferência do ruído elétrico e magnético e, também, a amplificação mecânica do sinal original para obter uma maior exatidão das leituras e do controle automático do equipamento.
\end{abstract}

Palavras-chave: strain gage, próteses, pilar protético, análise de sinal, controle.

\section{Introduction}

The controls of the stresses on the bone-implant and implant-abutment interfaces are crucial for the performance of an implant. Dental implants are a class in itself due to its size and chemical and biological environment. This paper presents a study of the electric signals from a strain gage used in a custom made laboratory micro torque meter specially developed to evaluate the influence of the bone-implant and implantabutment screwed interfaces on the micro torque signals [1]. The original electric signals were acquired via National Instruments (NI) hardware in real time processed with the Labview ${ }^{\circledR}$ software [2] for the evaluation of noise and its relation to the physical values of interest and equipment precision. The results indicate the need of careful attention to the noise pickup and controls. Furthermore, the mechanical amplification of the original signal shows a solution for the problem of in order to obtain higher accuracy of the equipment and automated control of the equipment, without amplifying the electronic noise.

\section{Objective}

The objective of this study was to show the development of the data acquisition system using National Instruments hardware and real time processing for the automation a micro torque meter. 


\section{Blucher Proceedings \\ VI Encontro Científico de Física Aplicada}

\section{Blucher}

\section{Experimental}

A prototype micro torque meter was built in order to evaluate the performance of dental implants and abutments in an in vitro experimental condition, see Fig. 1.

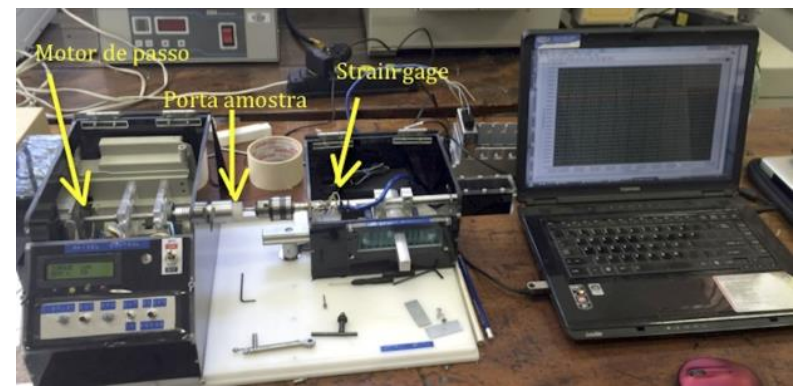

Figure 1. Image revealing the inner and main parts of a prototype micro torque meter.

This initial results indicate and provided data for a project of a new improved equipment. A strain gage was placed on the surface of the torque bar subjected to the torsional efforts of the test, Fig. 2.

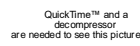

Figure 2. Image of the detail of a strain gage placed on the torque tube.

Signals from the strain gage were addressed to a channel of a NI9235 strain gage quarter-bridge data acquisition module, connected to compactDAQ® rack.

A virtual instrument or front panel, Fig. 3, was designed to allow the acquired data to be recorded, processed and analyzed in the time and frequency domains to allow the diagnostic evaluation of the data acquisition system and the mechanical behavior of the implants and abutments.

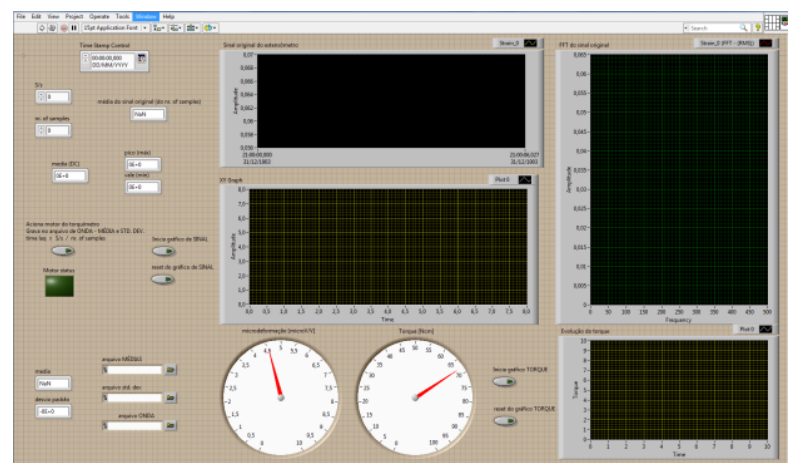

Figure 3. Image of the virtual instrument or front panel designed to analyze strain gage signals.

\section{Results and discussion}

Previous results indicate that the data acquisition system is very sensitive to electric, magnetic and electromagnetic noise since noise is present in the strain gage signal as will be shown ahead.

A experimental torque against micro strain calibration was performed and the results are shown in Fig. 4. The microstrain error bars equals 3 times the standard deviation as an attempt to hold $99 \%$ of the data inside this range, despite the recorded noise being mainly white, with $60 \mathrm{~Hz}$ multiples were present. Data was acquired at a $1000 \mathrm{~Hz}$ sample rate with a 1000 points data buffer. The statistical mean was calculated, with an associated $3 \%$ statistical error of the mean.

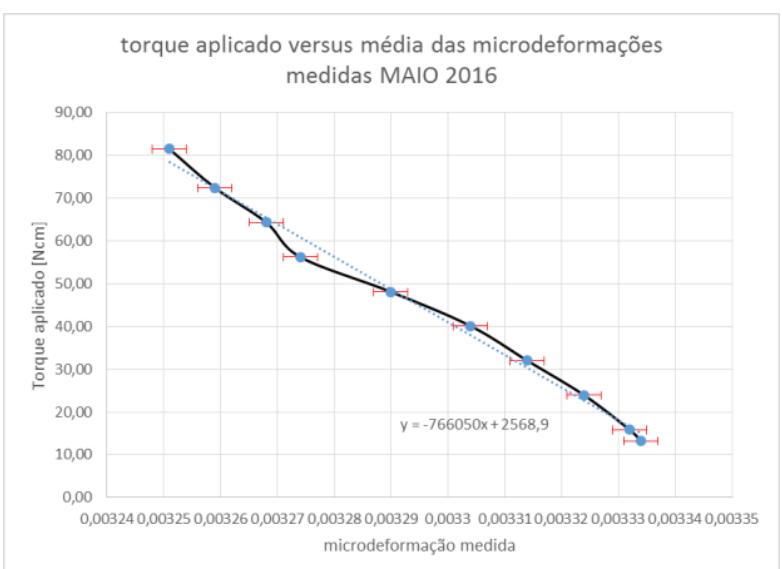

Figure 4. Experimental torque against microstrain calibration curve for the tube torque as shown in Fig. 1.

The tendency line shown in Fig. 4 is of fundamental importance to be used in the programming of a PLC under development for the automatic control of a new micro torque meter.

The propagated error on the torque scale was around 2 $\mathrm{Ncm}$ regarding 3 times the standard deviation of the mean microstrain throughout the torque scale. Since the source of error in the microstrain scale is due to the electrical noise, the error in the torque scale will be minimized with electric noise reduction [3].

The curved behavior of the applied torque versus microstrain plot is probably associated to thermal effects, related to the strain gage self-heating.

\section{CONCLUSION}

The error bars associated to the micro strain data is the most important problem to be dealt at this point of the study. Dealing with the standard deviation is not the ideal but is adequate as a first approach to the precision of the equipment. Otherwise, considering the statistical error of $1 / \sqrt{n}$ would be a better approach yielding a $3 \%$ 
error of the mean value for a buffer with 1000 points throughout the torque scale. The two different approaches have their pros and cons so a careful and detailed evaluation of them must be carried out.

The use of the knowledge from this study is being of great importance to the development of the electronic control via a PLC as well as to tailor the control data acquisition system for a new improved micro torque meter.

It was clearly concluded that the noise control is fundamental for the enhancement of the torque measurement precision demanding a careful study of its sources and the incorporation of these solution on a new micro torque meter.

It is also observed that any means of increasing the gain of the electric signal from the strain gages without raising the electrical noise would benefit the signal/noise ratio an then the precision of the micro torque meter. This issue is currently under investigation by the authors and a solution of 3 times the micro strain signal raise was obtained with modifications of the micro torque meter mechanical parts. The influence on the signal/noise ratio is under evaluation.

\section{REFERENCES}

[1] Pascoato, R.; Nogueira, E. J.; Aranha L. C.; Jesus, E. R. B.; Mucsi, C. S.; Rossi, J. L. Mechanical design of components, for precise measurement of viewing torques in dental implant evaluation. Congresso Científico da Semana Nacional de Ciência e Tecnologia no IFSP 20-23 de outubro de 2015 - Instituto Federal de São Paulo, Bragança Paulista, SP, Brazil. In Portuguese.

[2] Graphical system development environment LabVIEW. Available in <http://www.ni.com/labview/pt/>. Accessed in 26 May 2016. In Portuguese.

[3] Noise Control in Strain Gage Measurements, Tech Note TN-501-2. Available in

<http://www.vishaypg.com/docs/11051/tn501.pdf>. Accessed in 26 May 2016. 